\title{
Penyuluhan Dampak Game Online Bagi Siswa SMP X Kota Palangkaraya, Kalimantan Tengah
}

\author{
Dea Stella Ananda ${ }^{1 *}$, Yakub Ricky Widyatma ${ }^{2}$, Made Bagus Kresna Digjaya ${ }^{3}$, Pramana \\ Anantasadhu ${ }^{4}$ \\ 1,2,3,4 Program Studi Sistem Informasi, Fakultas Teknologi Industri, Universitas Atma \\ Jaya Yogyakarta \\ *email: deastellaa@gmail.com
}

Informasi Artikel

Diterima Redaksi : 13 Desember 2020

Revisi Akhir : 2 Januari 2021

Diterbitkan Online : 28 Januari 2021

Kata Kunci:

dampak, game online, remaja, sekolah daring.

\section{PENDAHULUAN}

Perkembangan game online yang sangat pesat terjadi beberapa waktu belakangan ini. Game online yang dulunya hanya bisa dimainkan di komputer, kini berkembang dapat dimainkan di gawai. Karena pengaruh itu, remaja di zaman sekarang sangat susah lepas dari yang namanya game online. Disini game online juga bisa diibaratkan sebagai pedang bermata dua yaitu ada sisi positif maupun negatifnya.

Beberapa orang tua juga masih cenderung memiliki pola pikir bahwa bermain game online itu tidak menguntungkan dan cemas karena putraputri mereka akan susah dalam bersosialisasi, maka lebih memaksakan putra-putri mereka untuk belajar yang giat agar memiliki nilai yang memuaskan di

\begin{abstract}
Abstrak
Game online sering disebut sebagai pemicu para siswa menjadi malas belajar, juga membuat kepatuhan siswa/i terhadap orang tua dan guru menjadi berkurang. Solusi yang kami berikan adalah mengedukasi adik-adik SMP ini dengan memberikan penyuluhan bagaimana game online dapat menjadi sesuatu yang positif jika mereka mau menekuni dengan serius. Penyuluhan ini kami lakukan kepada siswa-siswi SMP X Palangka Raya sebagai bentuk pengabdian kepada masyarakat dan mengangkat judul "Sosialisasi Dampak Game Online terhadap Siswa/i SMP Selama Sekolah Daring”. Pendekatan yang dilakukan untuk terciptanya solusi dan pemahaman baik terhadap suatu permasalahan atau akibat dari adanya game online. Kegiatan ini dilakukan untuk menjawab permasalahan yang ada pada aspek sosial, mental, emosional, dan keluarga. Peran sekolah di sini bertujuan sebagai objek sosialisasi, maka sosialisasi ini bisa terwujud. Bentuk sosialisasi berupa video yang diupload ke media sosial, yaitu Youtube. Dengan terlaksananya pengabdian ini, siswa/i SMP X Palangka Raya sudah mengetahui dampak yang didapatkan jika bermain game online tidak kenal waktu. Mereka akan lebih bijaksana dalam bermain game dan bisa membagi waktu agar tidak terlalu sering bermain game, serta melakukan aktivitas di luar rumah bersama teman teman agar memiliki relasi yang lebih baik.
\end{abstract}

sekolahnya, atau memaksa putra-putri mereka agar memiliki minat ke arah musik, tari, olahraga, atau kegiatan lainnya daripada bermain game online di gawai.

Dampak yang kurang baik atau sisi negatif dari Game Online itu memiliki kecenderungan untuk membuat para pemain berlama-lama menatap komputer maupun gawai sehingga melupakan waktu untuk belajar, makan, tidur, dan melakukan hubungan dengan lingkungan disekitarnya karena mereka lebih banyak menghabiskan waktunya untuk bermain game. Rasa keingintahuan yang besar dan ketertarikan yang tinggi itulah terjadi berbagai perubahan baik dari segi fisik maupun psikis akhirnya menyebabkan banyak masalah yang timbul pada kehidupan remaja. Pada akhirnya banyak masalah yang terjadi pada remaja, 
baik dari segi kesehatan, pendidikan, dan lain sebagainya[1]. Dalam versi terbaru ICD-11, WHO menyebut bahwa kecanduan game merupakan disorders due to addictive behavior atau gangguan yang disebabkan oleh kebiasaan atau kecanduan[2]. Selain merusak kontrol terhadap diri, kecanduan game online juga dapat menghambat keterampilan sosial pada remaja, padahal keterampilan sosial merupakan aspek tingkah laku sosial yang penting untuk diperhatikan[3].

Tak hanya itu dampak negatif yang dapat ditimbulkan jika anak-anak yang terus atau menghabiskan sebagian besar waktunya untuk bermain game itu bisa mulai mengabaikan keselamatannya, itu terjadi karena remaja terkadang suka bermain game sambil berjalan[4]. Game seperti peperangan, perkelahian hingga sampai membunuh juga bisa berdampak buruk untuk kehidupan di dunia nyata orang dewasa maupun remaja karena mereka bisa mencontohkan apa yang bisa dimainkan. Mungkin hasrat untuk itu tidak langsung timbul, tetapi jika sering memainkannya maka bisa emosinya meluap dan tidak menutup kemungkinan untuk dilampiaskan kepada lingkungan sekitar.

Akan tetapi, tentu saja bermain game online juga memiliki sisi positifnya, yaitu dapat mengembangkan kemampuan dalam mengatur kelompok dan memimpinnya, mengembangkan optimisme, mampu berdamai dengan frustasi dan kecemasan dengan cara yang adaptif [5]. Namun juga terdapat dari studi lainya yaitu bermain game online secara positif mampu mengembangkan kemampuan visual-spasial seseorang melalui proses berlatih mengolah informasi spasial dari layar monitor[6].

Selain yang di sebutkan di atas sisi positif yang lain yaitu salah satunya mengikuti lembaga besar seperti e-sport yang bagi yang merasa memiliki skill dalam game yang digeluti. Disana kita akan diarahkan cara bermain game yang benar dan mungkin nantinya bisa mengharumkan nama indonesia karena sekarang ada SEA GAME cabang e-sport. Oleh sebab itu kami memberikan beberapa solusi selain di yang atas, yang tepat untuk mengatasi permasalah tersebut adalah melakukan pengabdian kepada pelajar SMP berupa sosialisasi yang berjudul "Penyuluhan dampak Game Online bagi pelajar SMP selama sekolah daring".

Tujuan kelompok kami dalam melakukan pengabdian ini adalah memberi penyuluhan kepada siswa-siswi SMP X Palangka Raya mengenai dampak yang didapat jika terlalu sering bermain game online. Dampaknya bisa positif dan juga negatif. Agar anak-anak tahu bagaimana cara untuk memilah bermain game yang baik dan benar. Lalu juga dampak negatifnya jika mereka bermain hingga lupa waktu untuk belajar dan melakukan aktivitas lain, maka akan berpengaruh buruk juga ke sisi psikologis mereka. Dampak positifnya jika mereka menekuni game online tersebut, mereka bisa bergabung dengan komunitas game online yang mereka minati. Disana mereka akan mendapatkan bimbingan serta dilatih untuk menjadi profesional game agar dapat mengikuti lomba game online nasional maupun tingkat internasional yang sedang menjadi tren saat ini.

\section{METODE}

Sebelum melakukan penyuluhan ke siswa/i SMP X, kami menganalisis situasi terlebih dahulu dengan menyebarkan kuesioner kepada orang tua/wali siswa/i SMP X. Setelah mendapatkan hasil dari situasi, kami menyiapkan materi penyuluhan agar sesuai dengan situasi yang ada.

Pendekatan yang dilakukan untuk terciptanya solusi dan pemahaman baik terhadap suatu permasalahan atau akibat dari adanya game online. Kegiatan ini dilakukan untuk menjawab permasalahan yang ada pada aspek sosial, mental, emosional, dan keluarga. Menurut Maslow, perasaan diterima dan dihargai merupakan kebutuhan dasar yang dimiliki manusia sebagai cara untuk mendapatkan keuntungan psikologis berupa kebahagiaan dan keutuhan kehidupan batinnya[7]. Maka peran guru di sekolah dan keluarga di rumah menjadi penting untuk kesehatan psikologis remaja SMP ini, mengingat kita masih berjuang melawan pandemi, yang membuat kita harus sehat pikiran dan mental. Dengan situasi tersebut, tim kami membuat materi penyuluhan yang mencakup:

1. Pengertian game Online

2. Dampak Positif dalam bermain game Online 
3. Dampak Negatif dalam bermain game Online

4. Tips and Trik Mengatur Waktu bermain game online

5. Hal - hal yang diterapkan untuk menyikapi game online ke arah positif.

Bentuk penyuluhan ini nantinya berupa video yang diupload di Youtube dan disosialisasikan kepada siswa/i SMP X yang sudah disepakati dengan pihak sekolah, kemudian peserta penyuluhan akan diberi post-test setelah menonton video. Penyuluhan ini diberikan dengan tujuan memberitahu dampak game online, baik dari sisi negatif, sisi positif, dan tips and trick dalam mengatur waktu dengan harapan mereka dapat bermain game online lebih cermat dan tidak meninggalkan tanggung jawab mereka sebagai siswa/i.

\section{HASIL DAN PEMBAHASAN}

Setelah kami mengetahui analisis situasi yang ada di SMP $X$ dan melakukan penyuluhan disana, kami mendapatkan hasil dari kegiatan kami ini. Yaitu, orang tua tidak menjelaskan dengan baik mengapa siswa/i ini dilarang untuk bermain game, ada juga orang tua yang membiarkan mereka bermain game sepuasnya, namun tidak sedikit orang tua yang bijaksana dalam mengatur jam bermain anaknya. Maka dengan penyuluhan yang kami berikan, siswa/i SMP X menyadari bahwa durasi mereka bermain game sangat tidak efektif, karena mereka bermain hanya untuk bersenang-senang, hanya sedikit yang berminat menjadi gamers profesional.

Dari hasil penyuluhan pada tanggal 27 November 2020, kami mendapatkan sebuah kejutan dari siswa/i yang sangat antusias menonton penyuluhan kami, bisa dilihat dari views dan pengisian melalui Google Form yang telah diberikan memberikan hasil yang sangat positif. Siswa/i SMP X menjadi tahu bahwa game online itu sendiri bisa memberikan dua dampak pada siswa/i yaitu negatif dan positif, untuk sisi negatifnya sendiri membuat siswa/i malas untuk belajar maupun mengerjakan tugas, dan sikap untuk menghargai mulai berkurang, kemudian menyebabkan gangguan pada psikis mereka, dan membuat mereka susah untuk bersosialisasi dengan teman sebayanya. Namun di balik sisi negatifnya itu sendiri ada sisi positif yang dimana membuat siswa/i itu sendiri bisa menjadi profesional gamers, bisa membagi waktu untuk belajar dan bermain game, jika bermain game online seperti strategi meningkatkan kecerdasan anak itu sendiri, dan memiliki banyak teman yang berada di luar kawasan pulau maupun daerah bahkan bisa memiliki teman di luar negeri.

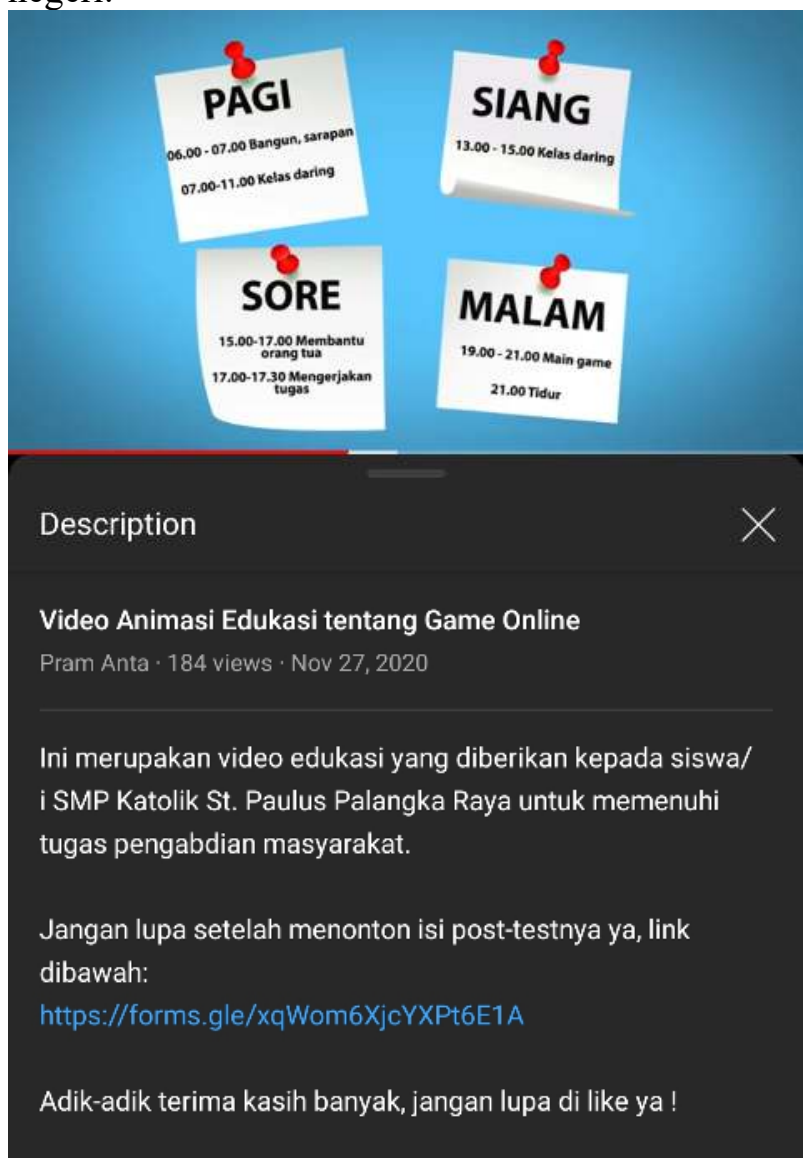

Gambar 1. Video Edukasi https://youtu.be/rxbyTysdOHo

\section{KESIMPULAN}

Kesimpulan yang dapat kami ambil adalah tujuan awal pengabdian masyarakat ini sudah tercapai, dapat dilihat bahwa setelah melakukan pengabdian kepada siswa-siswi SMP X Kota Palangka Raya, peserta yang menonton video penyuluhan tersebut mulai mengerti cara membagi waktu yang baik, mengambil sisi positif dan mengurangi sisi negatifnya. Sehingga kedepannya siswa-siswi mendapat nilai yang diinginkan dan game online bukan masalah lagi untuk pelajar SMP. Siswa/i SMP X sangat menikmati materi yang kami berikan, namun karena keterbatasan waktu dan tenaga, kami tidak bisa menggali materi lebih dalam, sehingga peserta penyuluhan merasa kurang puas dalam menonton video 
animasi yang kami berikan. Pendapat mereka mengenai penyuluhan ini juga positif, peserta penyuluhan menerima penyuluhan kami dengan sangat baik dan memberikan kami kritik dan saran yang membangun untuk kami kedepannya.

\section{SARAN}

Saran penulis adalah analisis situasi dapat diperjelas dan materi yang ingin disampaikan lebih digali lagi agar peserta penyuluhan lebih paham mengenai dampak game online ini. Dari pengabdian ini juga dapat dikembangkan cara penyampaian materinya, pemateri lebih komunikatif dalam menyampaikan materi, jadi walaupun penyuluhan secara online, suasana penyuluhan tidak membosankan.

\section{UCAPAN TERIMA KASIH}

Terima kasih kepada pihak sekolah SMP $\mathrm{X}$ di kota Palangka Raya yang mau menerima kami untuk melakukan pengabdian masyarakat ini sehingga bisa berjalan dengan baik dari persiapan hingga pelaksanaan penyuluhan.

Terima kasih juga kepada dosen pembimbing kami yang dengan sabar membantu kami dalam mempersiapkan pengabdian masyarakat dari pembuatan proposal hingga penulisan artikel ini.

Terima kasih kepada anggota kelompok yang mau berproses bersama, mau belajar bersama. Dan juga pihak-pihak yang tidak bisa kami sebutkan satu persatu, yang mau terlibat mulai dari persiapan pengabdian hingga penulisan artikel.

\section{REFERENSI}

[1] E. B. Santoso and H. Akbar, "Penyerapan Pengetahuan Tentang Hiv/Aids Pada Siswa Di Smk Endang Darma Ayu Sebelum Dan Sesudah Penyuluhan," Gema Wiralodra, vol. 9, no. 2, pp. 106-114, 2018, doi: 10.31943/gemawiralodra.vol9.iss 2.34 4.

[2] Edo S. Jaya, "WHO tetapkan kecanduan game sebagai gangguan mental, bagaimana 'gamer' Indonesia bisa sembuh?," The Conversation, 2018.

https://theconversation.com/who- tetapkan-kecanduan-game-sebagaigangguan-mental-bagaimana-gamerindonesia-bisa-sembuh-

99029\#: :text=Karena itu\%2C dapat dipahami bahwa,masuk sebagai gangguan kesehatan jiwa.

[3] J. M. Gottman and W. G. Graziano, "How Children Become Friends," Monogr. Soc. Res. Child Dev., vol. 48, no. 3, pp. 1-86, Nov. 1983, doi: $10.2307 / 1165860$.

[4] W. Fauziawati, "Upaya Mereduksi Kebiasaan Bermain Game Online Melalui Teknik Diskusi Kelompok," PSIKOPEDAGOGIA J. Bimbing. dan Konseling, vol. 4, no. 2, p. 115, 2015, doi:

10.12928/psikopedagogia.v4i2.4483.

[5] I. Granic, A. Lobel, and R. C. M. E. Engels, "The benefits of playing video games.," American Psychologist, vol. 69, no. 1. American Psychological Association, Granic, Isabela: Developmental Psychopathology Department, Behavioural Science Institute, Radboud University Nijmegen, Montessorilaan 3, Nijmegen, Netherlands, 6525 HR, i.granic@pwo.ru.nl,pp. 66-78, 2014, doi: 10.1037/a0034857.

[6] C. L. Groves and C. A. Anderson, "Handbook of Digital Games and Entertainment Technologies," Handb. Digit. Games Entertain. Technol., pp. 1-26, 2015, doi: 10.1007/978-9814560-52-8.

[7] Alwisol, Psikologi Kepribadian. UMM Press, 2009. 